\title{
ARM Export and Economiic Growth Nexus
}

\author{
Muhammad Zubair and Dr. Shahida Wizarat
}

\begin{abstract}
Using the balance panel techniques for top arm exporting countries USA, UK, France, Germany, Italy, China and Russia during1997-2013, our results suggest a positive significant effect of arm exports on economic growth. Moreover, the post $9 / 11$ growth rate of these countries has significantly increased as compared with the pre $9 / 11$ period.
\end{abstract}

Keywords - Arms exports, economic growth, Balance panel.

\section{INTRODUCTION}

$\mathrm{T}$ HE theory of permanent arms economy has had a significant impact on the political economy of war literature since the beginning of the neo Marxist paradigm.

The permanent arms economy originated with Sard, Oakes and Vance (1944) and was extended by the neo Marxist economist Michel Kidron in the late sixties who predicted a post-war

HYPERLINK "http://en.wikipedia.org/wiki/arms_race" arms race. They developed their argument on the ground that HYPERLINK "http://en.wikipedia.org/wiki/usa" USA would retain the character of a HYPERLINK "http://en.wikipedia.org/wiki/war_economy" war economy even during peace time and HYPERLINK "http://en.wikipedia.org/wiki/us_military_expenditure" the military expenditure of USA will remain large, reducing the percentage of the unemployed compared to the 1930s. Kidron extended the theory of the HYPERLINK "http://en.wikipedia.org/wiki/permanent_arms_economy" permanent arms economy and argued that HYPERLINK "http://en.wikipedia.org/wiki/capitalism" capitalism had been temporarily stabilized by the HYPERLINK "http://en.wikipedia.org/wiki/production_of_arms" production of arms, which acted as a counter HYPERLINK "http://en.wikipedia.org/wiki/tendency_of_the_rate_of_profit_ to_fall" tendency to the falling rate of profit (termed as the capitalist crisis). He argued that capitalism is always threatened by the booms and busts of the business cycles, so the weapon produced in the permanent arms economy can be used to avoid these fluctuations through building the armament industry and exporting the arms overseas.

This solution to the capitalist crises through increasing armament trade has intensified in recent years, specially since 9/11 as observed by the Stockholm International Peace Research Institute (SIPRI) in its 2015 Yearbook:

Muhammad Zubair Senior Lecturer IoBM, Karachi, Pakistan Dr. Shahida Wizarat Director research, IoBM, Karachi, Pakistan
"The United States remains the leading arms exporter increasing sales by 23 percent, with the country's share of the global arms trade at 31 percent. Ninety-four countries imported US made weaponry, with the Middle East accounting for 32 percent of the purchases. The United States and Russia made up 58 percent of the global trade in conventional arms. Chinese sales have made a breakthrough in the last four years increasing exports by 143 percent, surpassing Germany and leaping from ninth to the third position, however, still far behind the US and Russia” (SIPRI) Yearbook2015)

In this study we will empirically investigate whether arms trade has a significant role in economic growth of the top arms exporting countries. We will also try to explore the significance of incidents such as 9/11 in affecting the growth rates of arms exporting countries. Section-II of the paper discusses the literature, while the data and the econometric model are contained in Section-III, while the results and conclusions are presented in Section-IV.

\section{II.LITERATURE REVIEW}

In the literature considerable attention has been given to the association between military expenditure and economic growth which is one dimension of the armament economy. The other dimension of the militarized economy, arms trade and economic growth nexus has been much less researched. The literature on defense spending and economic growth has mixed results as some findings suggest that military spending affects economic growth positively, while others find an inverse association between military expenses and economic growth. Those who suggest growth enhancing effects of military spending argue that military research and development (R\&D) stimulates aggregate demand, infrastructural development and spillover effects of technology for civilian use, for example Pavel (2004). In the same way Benoit $(1973,1978)$ extended his argument that as a result of an increase in defense expenditure, aggregate demand will increase which may increase the utilization of capital stock (especially in developing countries), consequently the purchasing power, profit rate and investment will increase. So the defense expenditure component of aggregate demand will generate short term multiplier effects as well as higher long-run rates of economic growth. As Benoit (1973 and 78) focused on developing countries when he discussed the relationship between military spending and economic growth via the aggregate demand channel, Fredericksen and Looney (1983) have looked at the effects of defense spending on economic growth separately for resource rich and resource scarce LDCs. They found that defense expenditure increases economic growth in resource-rich LDCs but not in resource scarce 
LDCs.

Those who found the inverse relationship between military spending and economic growth build their argument on the reallocation of resources hypotheses. They argue that huge spending on defense causes reallocation of resources from the more productive market ventures to the less productive ventures (military) financed with taxes, which create welfare losses and reduce labor supply (Pavel 2004). Similarly Mankiw, Romer and Weil (1992) have explained the inverse relationship between defense spending and economic growth in terms of the opportunity cost of resources employed due to military buildup. They argued that human capital (the large number of skilled workers and talented scientists) employed by the military could contribute more productively elsewhere in the economy. There are a number of studies which find an inverse relationship between military expenditure and economic growth and include Heo (1998) Perkins (2001) and Maizels and Nissanke (1986).

Although only a few studies have studied the trade aspects of the armament economy, recently some research has been done in this area. Those who found a significant impact of arms trade on economic growth have highlighted numerous channels through which arms trade can affect economic growth. For instance, Pavel (2007) discovered that both military spending and arms exports leads to lower economic growth, but military spending is less detrimental when the country is a net arms exporter. He argued that arms exports reflect the technological development in arms exporting countries, therefore developed countries could experience greater spillover effects of technology, which may enhance their growth rates. Similarly, if an export led economy is a net arms exporter, its growth rate will be affected via the aggregate demand channel, which could affect its economic growth. ZhengQi and Liu (2014) suggest a significant positive effect of arm trade on growth. Another aspect which explain the arms trade and growth relationship is conflict. Using panel data and GMM estimators for the developed countries (DCs) and the less developed countries (LDCs), Wizarat reports a positive and significant impact of conflict on DC GDP and a negative and significant impact on LDC GDP during the period 1980-2009. (Wizarat, 2014)

Much of the empirical literature explaining the arm economy and growth nexus has some limitations. First, much of the empirical research on the impact of military spending on economic growth has explained the internal dynamics of this phenomenon only, while the external factors which explains the trade dynamics of defense spending is less elaborated in the empirical literature. For instance, if a country has negative impact of defense spending on economic growth, it can offset this effect by exporting arms to the other countries. Second, most of the studies explaining military spending and economic growth nexus have the same model for the countries which are net exporters and net importers (particularly LDCs) of arms. Third, the impact of structural changes, wars and other events which exogenously boost up the armament industry are much less emphasized in the empirical literature.

\section{DATA AND ECONOMETRIC MODEL}

We use a Cob Douglas production function to study the relationship between economic growth and the explanatory variables, which is denoted by equation (1).

Yit $=\alpha i t+\beta 0$ AREXPit $+\beta 1 \mathrm{Nit}+\beta 2 \mathrm{Kit}+\beta 3 \mathrm{MILTit}+\beta 4$

WARit+ $\mu$ it

Writing eq (1) in estimable form gives eq (2)

$\ln Y i t=\alpha i+\beta 0 \ln ($ AREXPit $)+\beta 1 \ln (\mathrm{Nit})+\beta 2 \ln (\mathrm{Kit})+\beta 3 \ln$

$($ MILTit $)+\beta 4($ WAR $)+\mu$ it

Where

Ln Y it $=\log$ of GDP of country i at time $t$

Ln AREXPit $=\log$ of arms exports from country $i$ at time $t$

$\ln \mathrm{N}$ it $=\log$ of labour in country $\mathrm{i}$ at time $\mathrm{t}$

$\ln \mathrm{Kit}=\log$ of capital in country $\mathrm{i}$ at time $\mathrm{t}$

$\ln$ MILT it $=\log$ of military expenditures in country $i$ at time $t$ $\mathrm{WAR}=$ dummy for war which has a value of 1 for the period after $9 / 11$ and 0 for the period prior to $9 / 11$.

$\mu$ it $=$ error term.

We are using panel data of arms exporting countries US, UK, France, Germany, Italy, Russia and China for the period 1997 to 2013 obtained from World Development Indicators (WDI), World Bank.

\section{EMPIRICAL FINDINGS}

The empirical results show that all the variables including arms exports, labour, capital, military expenditure and WAR are statistically significant. The coefficient for arms exports gives interesting insight as $1 \%$ increase in arms exports of top arms exporting countries causes 39\% increase in GDP of the arms exporting countries. The magnitude of the coefficient on capital $(\mathrm{K})$ is very high and positive, which is consistent with the theory. It shows that $1 \%$ increase in capital leads to $91 \%$ increase in GDP, which seems very high, but we are using the data of technologically advanced countries, where the role of capital formation would be significant as compared with labour. The coefficient on labour is negative, but this may be different for different countries. For example, in China where labor has a more significant contribution in the explanation of the dependent variable GDP (Y) but in the US and UK labour has a much less significant role in GDP growth. Military expenditure has an inverse relationship with GDP growth showing that a $1 \%$ increase in military spending leads to $11 \%$ reduction in GDP growth (significant at 2\%) for the top arms exporting countries. In this case our results are consistent with Heo (1998) Perkins (2001) and Maizels and Nissanke (1986). Our results also endorse Pavel (2007) who suggested that military spending is less detrimental for nations which are net arms exporters. WAR which is a qualitative variable included to capture the impact of $9 / 11$ as such incidents can boost arm exports has a significant impact on the growth of developed as well as developing countries. Our results suggest that the GDP growth of top arm exporting countries increased 34\% post 9/11 as compared with period prior to 9/11. This result brings to the fore the importance of conflicts and wars in increasing GDP in arms producing countries and lends support to the Marxist view that death and destruction in the developing world brings prosperity to rich countries. 


\section{V.CONCLUSION}

Using the balance panel techniques for top arms exporting countries USA, UK, France, Germany, Italy, China and Russia for the period 1997-2013 our results suggest a positive significant effect of arms exports on economic growth. This finding is further corroborated by the finding that post $9 / 11$ growth rate of these countries has significantly increased as compared to the pre 9/11 period. These are important findings and lend strong support to the permanent arms economy postulated by Sard, Oakes and Vance (1944), Kidron (1967) and the more recent finding of Wizarat (2014) that one percent increase in conflict increases rich countries GDP by $7.7 \%$. The fact that the Great Recession in 2008 was followed by massive increase in conflict in the Middle East, Africa and Asia and the resulting improvement in the growth rates of some rich arms producing countries is food for thought for those who value human life and the suffering that material prosperity is causing in the less developed countries.

\section{REFERENCES}

[1] Yakovlev, Pavel, 2004, Do Arms Exports Stimulate Economic Growth?

[2] Yakovlev, Pavel, 2007, ARMS TRADE, MILITARY SPENDING, AND ECONOMIC GROWTH, Defence and Peace Economics https://doi.org/10.1080/10242690601099679

[3] Kidron M.(1967) The permanent arms economy, Internet.

[4] ZhengQi Fang, SiQi Liu, 2014, RESEARCH ON THE MOTIVATION OF CONVENTIONAL WEAPONS EXPORTING - EMPIRICAL ANALYSIS BASED ON PANEL MODEL, Review of the Air Force Academy

[5] Benoit, E. 1973. "Defense and Economic Growth in Developing Countries" Boston:

[6] D.C. Heath \& Co.

[7] Benoit, E. 1978. "Growth and Defense in Developing Countries," Economic Development

[8] And Cultural Change

[9] Fredericksen, P.C., and R.E. Looney. 1982. "Defense Expenditures and Economic

[10] Growth in Developing Countries: Some Further Empirical Evidence," Journal

[11] of Economic Development

[12] Mankiw, G., Romer, D., and Weil, D. 1992. "A Contribution to the Empirics of

[13] Economic Growth," The Quarterly Journal of Economics, May

[14] Perkins, Dwight, et. al. 2001. Economics of Development, 5th edition. W.W. Norton.

[15] SIPRI Yearbook, 1970-1985.

[16] Maizels, A., and M. Nissanke. 1986. "The Determinants of Military Expenditures in

[17] Developing Countries," World Development

[18] Heo, Uk. 1998. "Modeling the Defense-Growth Relationship around the Globe,"

[19] Journal of Conflict Resolution

[20] Wizarat Shahida, 2014, NATURAL RESOURCES, CONFLICT AND GROWTH: UNCOVERING THE TRANSMISSION MECHANISM, Asian Economic and Financial Review, 2014, 4(8): 987-1000

[21] SIPRI 2015, Year book 